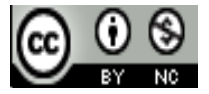

Jurnal Pendidikan Dasar Indonesia is licensed under

A Creative Commons Attribution-Non Commercial 4.0 International License

\title{
IMPLEMENTASI PENDIDIKAN KARAKTER DI SEKOLAH MELALUI KETELADANAN DAN PEMBIASAAN
}

\author{
Evinna Cinda Hendriana ${ }^{1)}$, Arnold Jacobus ${ }^{2)}$ \\ 1) Prodi Pendidikan PGSD STKIP Singkawang, Kalbar, Indonesia \\ E-mail: evinnacinda@yahoo.com \\ 2) Sekolah Dasar Negeri 90 Singkawang, Kalbar, Indonesia \\ E-mail: arnold.jacobus@yahoo.com
}

\begin{abstract}
Pendidikan karakter merupakan berbagai usaha yang dilakukan oleh berbagai personil sekolah, bahkan yang dilakukan bersama-sama dengan orang tua dan anggota masyarakat untuk membantu anak-anak dan remaja agar menjadi atau memiliki sifat peduli, berpendirian, dan bertanggung jawab. Menyikapi pentingnya pendidikan karakter, maka sangat diperlukan pendidikan karakter di sekolah untuk mewujudkan peradaban bangsa dengan memberikan keteladanan dan pembiasaan. Bagian pertama dalam studi ini akan memperkenalkan makna pendidikan karakter, fungsi dan tujuan pendidikan karakter. Bagian kedua akan membahas nilai-nilai pendidikan karakter dan pentingnya pendidikan karakter. Akhirnya, bagian terakhir dari tulisan ini akan menjelaskan tentang implementasi pendidikan karakter di sekolah melalui keteladanan dan pembiasaan.
\end{abstract}

Keywords: Pendidikan karakter, Keteladanan, Pembiasaan

\section{Pendahuluan}

Saat ini, bangsa Indonesia memiliki musuh besar, yaitu kemiskinan, kebodohan, merajalelanya korupsi, kurangnya penegakan hukum, tawuran pelajar, serta pragmatisme dan budaya instan yang semakin menguat. Banyaknya penyimpangan dan prilaku negatif yang terjadi di lingkungan masyarakat kita perlu dicermati secara bersama. Persoalanpersoalan tersebut muncul karena lunturnya nilai-nilai karakter bangsa. Karakter merupakan nilai-nilai perilaku manusia yang berhubungan dengan Tuhan Yang Maha Esa, diri sendiri, sesama manusia, lingkungan dan kebangsaan terwujud dalam pikiran, sikap, perasaan, perkataan, dan perbuatan berdasarkan norma-norma agama, hukum, tata krama, budaya dan adat istiadat. Perbuatan menyimpang yang dilakukan oleh masyarakat kita saat ini disebut Anomaly. Elfindri, dkk dalam bukunya Soft Skill Untuk Pendidik mengartikan Anomaly adalah sesuatu yang ganjil dari yang seharusnya terjadi (Elfindri, 2011).

Padahal, Indonesia memerlukan sumberdaya manusia dalam jumlah dan mutu yang memadai sebagai pendukung utama dalam pembangunan. Untuk memenuhi sumberdaya manusia tersebut, pendidikan memiliki peran yang sangat penting. Hal ini sesuai dengan UU No 20 Tahun 2003 Tentang Sistem Pendidikan Nasional pada Pasal 3, yang menyebutkan bahwa pendidikan nasional berfungsi mengembangkan kemampuan dan membentuk karakter serta peradaban bangsa yang bermartabat dalam rangka mencerdaskan kehidupan bangsa. Pendidikan nasional bertujuan untuk berkembangnya potensi peserta didik agar menjadi manusia yang beriman dan bertakwa kepada Tuhan Yang Maha Esa, berakhlak mulia, sehat, berilmu, cakap, kreatif, mandiri, dan menjadi warga negara yang demokratis serta bertanggung jawab.

Pendidikan adalah usaha sadar dan terencana untuk mewujudkan suasana belajar dan proses pembelajaran agar peserta didik secara aktif mengembangkan potensi dirinya untuk memiliki kekuatan spiritual keagamaan, pengendalian diri, kepribadian, kecerdasan, akhlak mulia, serta keterampilan yang diperlukan dirinya, masyarakat, bangsa dan negara (Kemdiknas, 2003). Jalur pendidikan adalah salah satu alternatif yang dianggap cukup mampu mengatasi masalah tersebut. Pendidikan sebagai wahana preventif karena malalui pendidikan akan dibentuk generasi baru yang lebih baik. Menyikapi pentingnya pendidikan karakter, maka sangat diperlukan pendidikan karakter di sekolah untuk mewujudkan peradaban bangsa dengan memberikan keteladanan dan pembiasaan.

\section{Pengertian Pendidikan Karakter}

Kata "character" berasal dari bahasa Yunani charassein, yang berarti to engrave (melukis, menggambar), seperti 
orang yang melukis kertas, memahat batu atau metal. Berakar dari pengertian yang seperti itu, character kemudian diartikan sebagai tanda atau ciri khusus. Dalam kamus terbaru Bahasa Indonesia, karakter artinya sifat, akhlak, budi pekerti yang menjadi ciri khas seseorang. I.R Pedjawawijatna mengemukakan: "Watak atau karakter ialah seluruh aku yang ternyata dalam tindakannya (insani, jadi dengan pilihan) terlibat dalam situasi, jadi memang di bawah pengaruh dari pihak bakat, temperamen, keadaan tubuh, dan lain sebagaiannya" (Purwanto, 1999).

Pendidikan artinya proses pengubahan sikap dan perilaku seseorang atau kelompok dalam usaha mendewasakan manusia. Menurut Dinn Wahyudin, pendidikan adalah humanisasi (upaya memanusiakan manusia) yaitu suatu upaya dalam rangka membantu manusia (peserta didik) agar mampu hidup sesuai dengan martabat kemanusiaannya (Wahyudin, 2009). W.S. Winkel dalam bukunya yang berjudul Psikologi Pengajaran, mendefinisikan pendidikan ialah bantuan yang diberikan orang dewasa kepada orang yang belum dewasa, agar dia mencapai kedewasaan (Winkel, 1983). Pemerintah dalam UU RI No. 20 tahun 2003 memuat pengertian pendidikan, pendidikan adalah usaha sadar dan terencana untuk mewujudkan suasana belajar dan proses pembelajaran agar peserta didik secara aktif mengembangkan potensi dirinya untuk memiliki kekuatan spiritual keagamaan, pengendalian diri, kepribadian, kecerdasan, akhlak mulia, serta keterampilan yang diperlukan dirinya, masyarakat, bangsa dan negara (Kemdiknas, 2003).

Pendidikan karakter merupakan berbagai usaha yang dilakukan oleh berbagai personil sekolah, bahkan yang dilakukan bersama-sama dengan orang tua dan anggota masyarakat untuk membantu anak-anak dan remaja agar menjadi atau memiliki sifat peduli, berpendirian, dan bertanggung jawab (Daryanto, 2013). Berdasarkan pengertian di atas dapat ditarik kesimpulan bahwa pendidikan karakter adalah proses pengubahan sifat, kejiwaan, akhlak, budi pekerti seseorang atau kelompok orang agar menjadi dewasa (manusia seutuhnya/insan kamil).

\section{Fungsi dan Tujuan Pendidikan Karakter}

Sesuai dengan fungsi Pendidikan Nasional yang tertuang dalam UU RI No. 20 Tahun 2003 tentang Sisdiknas menyatakan bahwa Pendidikan nasional berfungsi mengembangkan kemampuan dan membentuk watak serta peradaban bangsa yang bermatabat dalam rangka mencerdaskan kehidupan bangsa, bertujuan untuk berkembangnya potensi peserta didik agar menjadi manusia yang beriman dan bertakwa kepada Tuhan Yang Maha Esa, berakhlak mulia, sehat, berilmu, cakap, kreatif, mandiri, dan menjadi warga negara yang demokratis serta bertanggung jawab.

Pendidikan karakter pada intinya bertujuan membentuk bangsa yang tangguh, kompetitif, berakhlak mulia, bermoral, bertoleran, bergotong royong, berjiwa patriotik, berkembang dinamis, berorientasi ilmu pengetahuan dan teknologi yang semuanya dijiwai oleh iman dan takwa kepada Tuhan Yang Esa berdasarkan pancasila.

\section{METODE}

Kajian pustaka merupakan salah satu metode yang ada penelitian. Kajian pustaka diambil dari kajian-kajian literature yang berkaitan dengan masalah yang dikaji . Teori yang mendasari masalah yang akan diteliti dapat ditemukan dengan melakukan studi kepustakaan. Peneliti dapat memperoleh informasi tentang penelitian yang ada kaitannya dengan masalah yang dikaji.

Studi kepustakaan merupakan studi tentang cara pengumpulan data dengan studi penelaahan dari buku literatur, catatan-catatan, dan laporan-laporan yang ada hubungannya dengan masalah yang dikaji (Nazir, 2003). Pohan dalam Prastowo (2012), kegiatan penyusunan kajian pustaka mempunyai tujuan untuk mengumpulkan informasi tentang kajian ilmiah, berupa teori-teori, metode, atau pendekatan yang pernah berkembang dan telah di dokumentasikan dalam bentuk buku, jurnal, naskah, catatan, rekaman sejarah, dokumen-dokumen yang terdapat di perpustakaan. Kajian literature pada penelitian ini menggunakan literature yang berkaitan dengan karakter dan literature yang berkaitan dengan karakteristik siswa sekolah dasar. Tinjauan literature ini berperan untuk meningkatkan nilai-nilai karakter dapat dijadikan untuk mengembangkan karakter yang ada dalam diri siswa.

\section{HASIL DAN PEMBAHASAN}

\section{Nilai-nilai Pendidikan Karakter}

Sumber-sumber nilai yang digunakan dalam penerapan pendidikan karakter bangsa di sekolah adalah: 1) Agama, 2) Pancasila, 3)Budaya, 4)Tujuan Pendidikan Nasional , 5) Undang-undang Republik Indonesia (UURI) No. 17 tahun 2007.

Nilai-nilai pendidikan karakter bangsa yang bersumber dari hal-hal di atas adalah sebagai berikut : 1) Religius, 2) Jujur, 3) Toleransi, 4) Disiplin, 5) Kerja Keras, 6) Kreatif, 7) Mandiri, 8) Demokratis, 9) Rasa Ingin Tahu, 10) Semangat Kebangsaan, 11)Cinta Tanah Air, 12) Menghargai Prestasi, 13) Bersahabat/Komunikatif, 14) Cinta Damai, 15) Gemar Membaca, 16) Peduli Lingkungan, 17) Peduli Sosial, dan 18) Tanggung jawab.

Meskipun telah terdapat 18 nilai pembentuk karakter bangsa, namun satuan pendidikan dapat menentukan prioritas pengembangannya. Di antara berbagai nilai yang dikembangkan, dalam pelaksanaannya dapat dimulai dari nilai yang esensial, sederhana, dan mudah dilaksanakan sesuai dengan kodisi masing-masing sekolah.

\section{Pentingnya Pendidikan Karakter}

Menurunnya kualitas moral dalam kehidupan manusia Indonesia dewasa ini, terutama di kalangan siswa, menuntut diselenggarakannya pendidikan karakter. Sekolah dituntut untuk memainkan peran dan tanggungjawabnya untuk menanamkan dan mengembangkan nilai-nilai yang baik dan 
membantu para siswa membentuk dan membangun karakter mereka dengan nilai-nilai yang baik.

Tulisan dalam Jawa Pos, 3 September 2009 bahwa dalam sebuah diskusi dengan tokoh-tokoh Madura, Dayak, dan Melayu di Singkawang baru-baru ini, mereka semuanya menyetujui dan mendukung ide tentang diselenggarakannya pelajaran pendidikan karakter berbasis multi-kulturalisme di sekolah. Hal ini didasari pertimbangan sebagai upaya mencegah terulangnya kembali dimasa yang akan datang konflik antarsuku bangsa yang pernah mereka alami barubaru ini (Zainal, 2012)

Pendidikan karakter diarahkan untuk memberikan tekanan pada nilai-nilai tertentu seperti rasa hormat, tanggungjawab, jujur, peduli, dan adil dan membantu siswa untuk memahami, memperhatikan, dan melakukan nilai-nilai tersebut dalam kehidupan mereka sendiri untuk mencapai kesuksesan hidup. Hasil penelitian psikologi sosial menunjukkan bahwa orang yang sukses di dunia ditentukan oleh peranan ilmu sebesar $18 \%$, sisanya $82 \%$ ditentukan oleh keterampilan emosional, soft skill (karakter), dan sejenisnya (Elfindri, 2011).

\section{Implementasi Pendidikan Karakter di Sekolah melalui Keteladanan dan Pembiasaan Membangun Karakter melalui Keteladanan}

Membangun karakter manusia tidak semudah membalik telapak tangan. Keteladanan merupakan salah satu imbauan untuk digunakan di dalam menapaki kehidupan bermasyarakat sehingga tanpa terasa dampak yang muncul sangat dahsyat.

Di sekolah peran guru amat penting dan perilaku guru akan menjadi ukuran keteladanan peserta didiknya. "Guru kencing berdiri, murid kencing berlari”, itu adalah pepatah yang disampaikan betapa seorang guru bisa menjadikan anak didiknya memiliki karakter baik atau buruk. Anang Santoso menulis sebuah artikel dalam Jurnal TEQIP mengatakan "guru yang hebat bagi saya adalah variabel yang amat penting dalam menyukseskan berbagai macam pembaharuan dalam kurikulum. Kurikulum boleh tidak sempurna, cacat, atau amburadul, tetapi guru hebat akan dapat mengolah kegiatan belajar mengajar menjadi bagus untuk menghasilkan keluarkan yang dapat dihandalkan. Apapun kurikulumnya guru tetap menjadi faktor penentu keberhasilan yang amat penting (Santoso, 2012).

Guru adalah pemimpin yang ada di kelas. Karakter pemimpin merupakan salah satu faktor yang menentukan kesuksesan dan kegagalan seorang pemimpin. Keberhasilan seorang pemimpin didasarkan pada upaya-upaya untuk menjadikan kebiasaan-kebiasaan positif sebagai bahan dari karakter pemimpin (Covey, 1997). Sedangkan Yusron Aminulloh mengatakan bahwa guru mempunyai peran strategis bagi masa depan bangsa, bahkan guru memegang peranan terpenting bagi kemajuan peradapan. Karena ia tidak hanya hidup untuk dirinya, tetapi adalah cermin indah bagi ratusan ribu bahkan jutaan anak didiknya yang tiap hari bersamanya (Aminulloh, 2014).

Salah satu tokoh yang bisa menjadi teladan bagi kita untuk mengajarkan pendidikan karakter adalah Rasulullah
Muhammad SAW. Beliau adalah merupakan sosok yang dapat ditiru bagaimana bertingkah laku terhadap diri beliau, bertindak dalam rumah tangga, pada anak-anak, istri, dan orang dewasa. Bahkan, Michael Hart, penulis buku Seratus Tokoh Paling Berpengaruh dalam Sejarah mengatakan bahwa "Muhammad bukan semata pemimpin agama, tetapi juga pemimpin dunia (Ary, 2007).

Oleh karena keteladanan beliau sehingga pengikutnya menjadi banyak sampai sekarang ini. Banyak perbuatan Muhammad SAW sewaktu mengajar muridnya dengan keteladanan, yang dapat kita terapkan dalam menyampaikan pendidikan karakter melalui keteladanan, diantaranya :

a. Nabi sering berdzikir kepada Allah SWT.

b. Nabi sangat dermawan

c. Nabi lebih mementingkan orang lain

d. Nabi memaafkan orang-orang yang bertindak zhalim

e. Nabi sangat tawadhu (rendah hati)

f. Nabi ikut serta dalam pembangunan masjid

g. Nabi melarang membalas dendam atas kematian cucu paman beliau.

Sikap-sikap beliau di atas langsung dilakukan agar para muridnya dapat mengikuti apa yang beliau sampaikan. Guru menjadikan sikap dan perilakunya sebagai teladan bagi muridnya. Sebuah peribahasa mengatakan "perkataan yang disertai dengan perbuatan lebih dapat menjelaskan dan lebih meresap ke dalam jiwa pendengar daripada ucapan semata. Pepatah Inggris mengatakan "Action speakers louder", artinya perbuatan dapat berbicara lebih nyaring daripada suara (Fadhl, 2012). Selain daripada itu guru juga harus mengajar dengan hati, seperti sebuah kisah seorang guru yang diceritakan oleh Munif Chatib dalam bukunya Gurunya Manusia (Chatib, 2014).

Beberapa teladan yang dapat kita lakukan dalam penanaman nilai-nilai karakter pada siswa, yaitu :

a. Religius, selalu taat beribadah/shalat, dan berdoa.

b. Disiplin, masuk dan keluar kelas tepat waktu

c. Bersahabat/Komunikatif, memberikan kesempatan kepada siswa untuk bertanya, dan memuji siswa yang bertanya atau menjawab pertanyaan guru.

d. Jujur, menepati apa yang dijanjikan.

e. Peduli lingkungan, memungut sampah yang berserakan di lantai.

Dalam sebuah buku yang berjudul Soft Skill untuk Pendidik (Elfindri, 2011), mengatakan bahwa ada beberapa tips untuk mengasah kejujuran anak, yaitu:

a. Guru mesti selalu menepati janji setiap yang dijanjikan kepada anak didiknya.

b. Menjaga disiplin dalam proses belajar, mengajar, serta proses ujian.

c. Inisiatif membuat kantin sekolah kejujuran. 
d. Memberikan kesempatan yang merata kepada seluruh peserta didik untuk menyusun kerja secara mandiri, dan melaporkan bagaimana proses pekerjaan dilakukan.

e. Mengoreksi tata cara penulisan, perkataan, dalam konteks kejujuran dalam mengutip, menyadur, dan melaporkan bahan bacaan.

\section{Membangun Karakter melalui Pembiasaan}

Aristotles (Covey, 1997) mengatakan "Kita adalah apa yang kita kerjakan berulang-ulang, keunggulan bukanlah suatu perbuatan, melainkan sebuah kebiasaan". Karakter kita pada dasarnya adalah gabungan dari kebiasaan-kebiasaan kita. "taburlah gagasan, tuailah perbuatan; taburlah perbuatan, tuailah kebiasaan; taburlah kebiasaan, tuailah karakter; taburlah karakter, tuailah nasib" begitu bunyi pepatah. Proses pembentukan karakter dapat digambarkan sebagai berikut:

Gagasan $\Rightarrow$ Perbuat $\Rightarrow$ Kebiasaan $\Rightarrow$ Karakter

Gambar 1. Alur Pembentukan Karakter

Berdasarkan gambar di atas dapat dijelaskan bahwa gagasan yang kita ketahui akan kita aktualisasikan dalam perbuatan, perbuatan yang dilakukan berulang-ulang akan menjadi suatu kebiasaan, kebiasaan yang dilakukan secara berulang/kontiniu akan membentuk suatu karakter.

Ary Ginanjar dalam bukunya ESQ mengatakan bahwa pembangunan karakter tidaklah cukup hanya dengan penetapan misi saja. Itu perlu dilanjutkan dengan proses yang terus menerus sepanjang hidup (Ary, 2007). Pembentukan suatu karakter dalam diri seseorang (peserta didik) tidaklah cukup dengan mengetahui nilai-nilai karakter apa saja yang akan dilakukan, namun harus disertai dengan perbuatan terus menerus sehingga menjadi suatu kebiasaan yang akan berujung kepada terbentuknya karakter.

Karakter, pada hakikatnya dapat dipandang sebagai sekumpulan kebiasaan yang terkoordinasi, apa yang kita pikirkan, rasakan, dan kerjakan, agar suatu tugas terlaksana. Pendapat ini sekiranya bisa menegaskan bahwa hakikat dari suatu karakter bukanlah hanya pada pemahaman, melainkan juga metode internalisasi kebiasaan. Seperti pandangan tentang penciptaan karakter dari buku Stephen R Covey, "taburlah gagasan, tuailah perbuatan; taburlah perbuatan, tuailah kebiasaan; taburlah kebiasaan, tuailah karakter; taburlah karakter, tuailah nasib". Artinya, untuk membangun karakter, tidak cukup dengan hanya menyampaikan apa saja yang harus kita lakukan, namun dibutuhkan sebuah mekanisme perbuatan yang terarah dan tiada henti secara berkesinambungan.

Daryanto (2013) dalam bukunya Implementasi Pendidikan Karakter di Sekolah menuliskan contoh pembiasaan karakter yang dapat kita lakukan di sekolah adalah sebagai berikut:

a. Religius: 1) berdoa sebelum dan sesudah pelajaran, 2) merayakan hari-hari besar keagamaan, 3 )memberikan kesempatan kepada semua peserta didik untuk melaksanakan ibadah.

b. Jujur: 1) menyediakan fasilitas tempat temuan barang hilang, tempat pengumuman barang temuan atau hilang, 2) transparasi laporan keuangan dan penilaian kelas secara berkala, 3) larangan menyontek.

c. Toleransi: 1) memberikan pelayanan yang sama terhadap seluruh warga kelas tanpa memebedakan suku, agama, ras, golongan, status sosial, dan status ekonomi, 2) memberikan pelayanan terhadap anak berkebutuhan khusus, 3) bekerja dalam kelompok yang berbeda.

d. Disiplin: 1) memiliki catatan kehadiran, 2) memberikan penghargaan kepada warga sekolah yang disiplin, 3) memiliki tata tertib sekolah, 4) menegakkan aturan dengan memberikan sanksi secara adil bagi pelanggar tata tertib, 5) membiasakan hadir tepat waktu.

e. Kerja Keras: 1) menciptakan suasana kompetisi yang sehat, 2) memiliki pajangan tentang slogan atau motto tentang giat bekerja dan belajar, 3) menciptakan kondisi etos kerja, pantang menyerah, dan daya tahan belajar.

f. Kreatif: 1) menciptakan situasi belajar yang menumbuhkan daya berpikir dan bertindak kreatif, 2) pemberian tugas yang menantang munculnya karyakarya baru baik yang autentik maupun modifikasi.

g. Mandiri: 1) menciptakan suasana sekolah yang membangun kemandirian peserta didik.

h. Demokrasi: 1) mengambil keputusan secara bersama melalui musyawarah dan mufakat, 2) pemilihan pengurus kelas secara terbuka, 3) mengimplementasikan modelmodel pembelajaran yang dialogis dan interaktif.

i. Rasa Ingin Tahu: 1) menciptakan suasan kelas yang mengundang rasa ingin tahu, 2) tersedia media komunikasi atau informasi.

j. Semangat Kebangsaan: 1) melakukan upacara rutin sekolah, 2) melakukan upacara hari-hari besar nasional, 3) menyelenggarakan peringatan hari kepahlawanan nasional, 4) memiliki program melakukan kunjungan ke tempat bersejarah, 5) mengikuti lomba pada hari besar nasional, 6) bekerja sama dengan teman sekelas yang berbeda suku, etnis, status sosial-ekonomi.

k. Cinta Tanah Air: 1) menggunakan produk buatan dalam negeri, 2) menyediakan informasi tentang kekayaan alam dan budaya Indonesia, 3) menggunakan bahasa Indonesia yang baik dan benar, 4)memajangkan foto presiden dan wakil presiden, bendera negara, lambang negara, peta Indonesia, gambar kehidupan masyarakat Indonesia (gambar pakaian adat, tarian adat, rumah tradisional, senjata tradisional, dan alat musik tradisional).

1. Menghargai Prestasi: 1) memberikan penghargaan atas hasil karya peserta didik, 2) memajang tanda-tanda 
penghargaan prestasi, 3) menciptakan suasan pembelajaran untuk memotivasi peserta didk berprestasi.

m. Bersahabat/Komunikatif: 1) berkomunikasi dengan bahasa yang santun, 2) pengaturan kelas yang memudahkan terjadinya interaksi peserta didik, 3) pembelajaran dialogis, 4) guru mendengarkan keluhankeluhan peserta didik.

n. Cinta Damai: 1) menciptakan suasana kelas yang damai, 2) membiasakan perilaku yang anti kekerasan, 3) pembelajaran yang tidak bisa gender, 4) kekerabatan di kelas yang penuh kasih sayang.

o. Gemar Membaca: 1) program wajib baca, 2) frekuensi kunjungan perpustakaan, 3) menyediakan fasilitas dan suasan menyenangkan untuk membaca, saling tukar bacaan, 4) pembelajaran yang meotivasi anak menggunakan referensi.

p. Peduli Lingkungan: 1) pembiasaan memelihara kebersihan dan kelestarian lingkungan sekolah, 2) tersedianya tempat pembuangan sampah dan tempat cuci tangan, 3) menyediakan kamar mandi dan air bersih, 4) pembiasaan hemat energi, 5) membangun saluran pembuangan air limbah dengan baik, 6) menyediakan peralatan kebersihan.

q. Peduli Sosial: 1) memfasilitasi kegiatan yang bersifat sosial, 2) melakukan aksi sosial, 3) menyediakan fasilitas untuk menyumbang, 4) berempati kepada sesama warga sekolah, 5) membangun kerukunan warga kelas.

r. Tanggung Jawab: 1) melakukan tugas tanpa disuruh, 2) pelaksanaan tugas piket secara teratur, 3) peran serta aktif dalam kegiatan sekolah, 4) mengajukan usul pemecahan masalah.

\section{KESIMPULAN}

Pendidikan karakter adalah adalah proses pengubahan sifat, kejiwaan, akhlak, budi pekerti seseorang atau kelompok orang agar menjadi dewasa (manusia seutuhnya/insan kamil). Pendidikan karakter pada intinya bertujuan membentuk bangsa yang tangguh, kompetitif, berakhlak mulia, bermoral, bertoleran, bergotong royong, berjiwa patriotik, berkembang dinamis, berorientasi ilmu pengetahuan dan teknologi yang semuanya dijiwai oleh iman dan takwa kepada Tuhan Yang Esa berdasarkan pancasila.

Sumber-sumber nilai yang digunakan dalam penerapan pendidikan karakter bangsa di sekolah adalah: 1) Agama, 2) Pancasila, 3) Budaya, 4) Tujuan Pendidikan Nasional. Nilainilai pendidikan karakter bangsa yang bersumber dari halhal di atas adalah sebagai berikut : 1) Religius, 2) Jujur, 3) Toleransi, 4) Disiplin, 5) Kerja Keras, 6) Kreatif, 7) Mandiri, 8) Demokratis, 9) Rasa Ingin Tahu, 10) Semangat Kebangsaan, 11) Cinta Tanah Air, 12) Menghargai Prestasi, 13) Bersahabat/Komunikatif, 14) Cinta Damai, 15) Gemar
Membaca, 16) Peduli Lingkungan, 17) Peduli Sosial, dan 18) Tanggung jawab.

Pendidikan karakter diarahkan untuk memberikan tekanan pada nilai-nilai tertentu seperti rasa hormat, tanggungjawab, jujur, peduli, dan adil dan membantu siswa untuk memahami, memperhatikan, dan melakukan nilai-nilai tersebut dalam kehidupan mereka sendiri untuk mencapai kesuksesan hidup. Pendidikan karakter di sekolah dapat diterapkan melalui keteladanan yang dilakukan guru dan juga dapat ditanam melalui pembiasaan secara terus menerus.

\section{DAFTAR PUSTAKA}

Aminulloh, Y. (2014). Ubah Mindset Pembelajaran. Yogyakarta: Aswaja Pressindo.

Ary, G. (2007). ESQ (Rahasia Sukses Membangun Kecerdasan Emosi dan Spritual). Jakarta: Arga.

Chatib, M. (2014). Gurunya Manusia. Bandung: Kaifa Learning.

Covey. (1997). The 7 Habits of Highly Effective People. Jakarta: Bina Rupa Akasara.

Daryanto, d. (2013). Implementasi Pendidikan Karakter di Sekolah. Yogyakarta: Gava Media.

Elfindri. (2011). Soft Skill untuk Pendidik. Jakarta: Baduose Media

Fadhl. (2012). Bersama Rasulullah Mendidik Generasi Idaman. Jakarta: Pustaka Iman Asy-Syafi'i.

Kemdiknas. (2003). Undang-Undang RI Nomor 20 Tahun 2003. Jakarta: Kementerian Pendidikan Nasional.

Purwanto, M. N. (1999). Psikologi Pendidikan. Bandung: PT. Remaja Rosdakarya

Santoso, A. (2012). Nafas Kreatif-Inovatif-Aktif (KIA) Dalam Pembelajaran Bahasa dan Sastra Indonesia. J-TEQIP Jurnal Peningkatan Kualitas Guru, 104.

Wahyudin, D. (2009). Pengantar Pendidikan. Jakarta: Universitas Terbuka. Winkel. (1983). Psikologi Pendidikan. Jakarta: Sanata Dharma.

Zainal, A. (2012). Pendidikan Karakter di Sekolah. Bandung: Yrama Widya. 